\title{
Degradation of Plasticized Poly(1-chloroethylene) Waterproofing Membranes used as a Building Material
}

\author{
Gregor Kravanja, ${ }^{1,2^{*}}$ Andrej Ivanič² ${ }^{2}$ and Samo Lubej ${ }^{2 *}$ \\ ${ }^{1}$ University of Maribor; Faculty of Chemistry and Chemical Engineering; Laboratory of separation processes and product design, \\ Smetanova ul. 17, 2000 Maribor, Slovenia \\ ${ }^{2}$ University of Maribor, Faculty of Civil Engineering, Transportation and Architecture, Smetanova 17, \\ 2000 Maribor, Slovenia \\ *Corresponding author:E-mail:gregor.kravanja@um.si andsamo.lubej@um.si
}

Received: $10-23-2020$

\begin{abstract}
In the present work, both unused plasticized poly(1-chloroethylene) membranes and membranes taken from a flat roof area were comprehensively analysed. First, tensile strength and elongation at breaking points were determined, followed by measurements of wettability. Secondly, morphological changes were analysed using scanning electron microscopy (SEM). To study chemical changes in aged membranes, Fourier transform infrared spectroscopy (FTIR) analysis in the attenuated total reflection mode (ATR) was used. Finally, thermogravimetric analysis and differential scanning calorimetry (TGA-DSC) were performed simultaneously to study thermal degradation. The results show obvious changes in the mechanical, physical and chemical properties of membranes caused by plasticizer loss. Surface microstructure becomes stiffer, which leads to contractions and the prevalence of voids. In cross-sectional area, average thickness values decrease. Due to the degradation of the plasticized waterproofing membranes, the roofing area had to be completely replaced.
\end{abstract}

Keywords: degradation; waterproofing membranes; plasticized PVC; SEM; FTIR; TGA-DSC

\section{Introduction}

Poly(1-chloroethylene) (PVC) is formed by the polymerization of vinyl chloride monomers. It is one of the most commonly used thermoplastics in construction, automotive, electrical parts and packaging. ${ }^{1}$ The properties of PVC can be significantly improved by adding plasticizers to make it more flexible and durable, which greatly expands its applications. ${ }^{2}$ " ${ }^{3}$ Plasticized PVC membranes are among the most commonly used waterproofing materials for roofing and geotechnical applications. However, practice shows that roofing membranes undergo chemical and physical changes when exposed to the combined effects of heat from solar radiation, near ultraviolet radiation, atmospheric oxidation, moisture and air pollution over long periods of time. ${ }^{4}$ As a result, plasticizers escape from the membranes through evaporation, leaching, and migration into other materials, causing significant changes in material flexibility, hardness, mass and elasticity. ${ }^{5}$

Despite extensive research in recent years in the field of testing of waterproofing membranes, there is still a shortage of specific studies on the durability, repairability and performance of such materials in roofing applications. The performance of plasticized PVC membranes has been evaluated by Dunn et al. ${ }^{6}$ who exposed the membranes to different climatic conditions for 4.5 years and reported the loss of plasticizer by evaporation. Similarly, Audouin et al. ${ }^{7}$ showed that increased temperature affects the migration of plasticizer from the membranes. They analysed the mass loss kinetics of plasticized PVC between $85{ }^{\circ} \mathrm{C}$ and $120^{\circ} \mathrm{C}$. Ito and Nagai ${ }^{8}$ investigated the influence of artificial ageing conditions on plasticized PVC. They found obvious changes in mechanical properties and microstructure through the thickness difference caused by plasticizer loss. Beer at al. ${ }^{9}$ investigated the long-term behaviour of plasticized PVC at different locations in Europe and North America. They confirmed reduced low-temperature flexibility and elongation at break points following plasticizer migration. Blanco et al. ${ }^{10}$ investigated the long-term behaviour of high-density polyethylene (HDPE), ethylene-propylene-diene monomer (EPDM) and plasticized PVC membranes, and reported that the shear strength of 
joints remained relatively unaffected by ageing despite the loss of plasticiser. Kositchaiyong et al. ${ }^{11}$ studied anti-fungal performance and mechanical-morphological properties of PVC and wood/PVC composites under the influence of soil and UV light, and concluded that UV weathering reduced the antifungal performance of the material from $81.4 \%$ to $28.3 \%$. Recently, environmental and economic comparisons of the life cycle performance of bituminous, synthetic, liquid and cement-based membranes suitable for flat roofs were reviewed by Goncalves et al. ${ }^{12}$ Paolini et al. ${ }^{13}$ investigated twelve roofing membrane products made of modified bitumen, PVC and polyolefin with different spectral reflectances in terms of energy demand for building cooling. It was found that weathering, soiling and biological growth significantly affect their solar reflectance and thus increase the energy consumption for air conditioning. Furthermore, as shown in our previous study, natural ageing under high humidity and thermal fluctuations can strongly influence the surface morphology and chemical composition of fibrous insulation material covered with plasticized PVC. ${ }^{14}$ A probable reason for the deterioration of the insulation was the damaged waterproofing PVC membrane. To ensure a fully functional and repair-free lifetime of a building, the degradation and durability estimation of covering water-repellent PVC-P membranes must be considered.

The objectives of this study were to evaluate the basic properties of plasticized PVC membranes and to measure the level of degradation by comparing unused membranes and weathered (aged) membranes from a flat roofing area. To the best of the authors knowledge, little information was reported in the literature on plasticized PVC membranes reinforced with a polyester mesh that can be used for mechanically fixed roof systems above thermal insulation. First, the mechanical properties and wettability of these membranes were comprehensively evaluated. Secondly, morphological changes in the microstructure were evaluated to determine the thickness and prevalence of voids that were probably created by plasticizer loss. To explain such plasticizer loss in the material, chemical changes were identified and quantified. Finally, the thermal stability of the samples was examined to determine the degree of thermal degradation

\section{Material and Characterization Methods}

New plasticized PVC membranes and membranes from the flat roof area, which are about 10 years old, were comprehensively analysed in a laboratory using various techniques.

\section{1. Samples from the Case Study}

$1.2 \mathrm{~mm}$ thin Standard Grey RAL 7047 plasticized PVC membranes reinforced with polyester mesh (Flagon
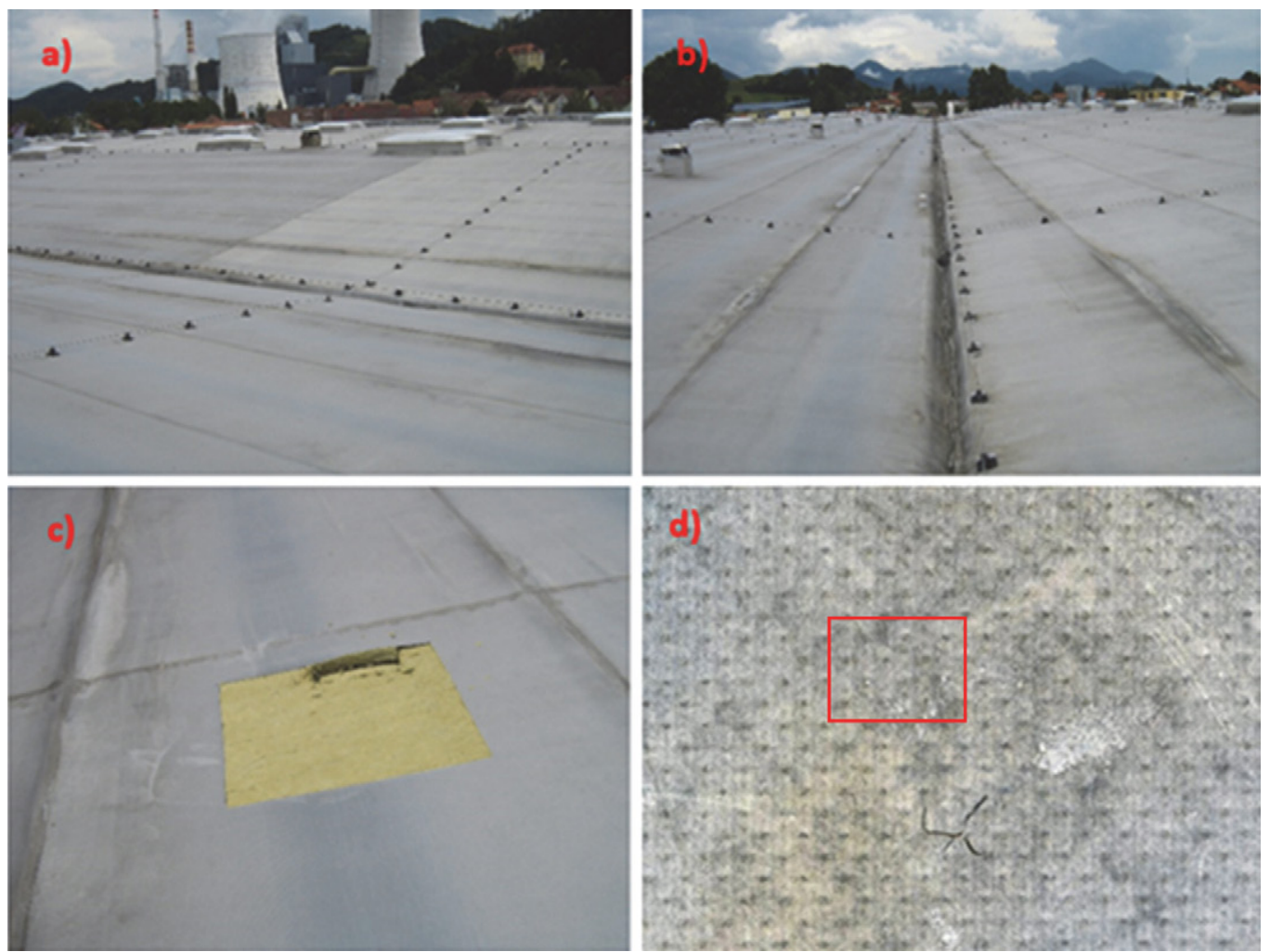

Figure 1. Plasticized PVC waterproofing membranes were taken from a flat industrial roof located in Slovenia, Central Europe (a, b) Extraction at sampling location 1 (c). Naturally aged and locally damaged plasticized PVC membrane (d). 
SR, Soprema, Italy) were obtained from the unvented roof of an industrial building located in Slovenia, Central Europe, which is characterized by a Cfb climate zone (Figure $1 \mathrm{a}, \mathrm{b}, \mathrm{c})$. Membranes are made of $51 \%$ pure PVC, $46 \%$ additives and $3 \%$ reinforcing material. The roof construction consisted of several layers: on top, a $1.2 \mathrm{~mm}$ thick plasticized PVC membrane; below, a $200 \mathrm{~mm}$ thick layer of thermal insulation with a density of $150 \mathrm{~kg} / \mathrm{m}^{3}$, followed by a $0.3 \mathrm{~mm}$ thick vapor barrier and trapezoidal sheet metal cladding anchored in steel roof beams (Appendix 1). An inspection revealed that the waterproofing membranes were damaged at several points where the photovoltaic modules were installed; the damage was visible as starshaped cracks (Figure 1. d).

Samples exposed to natural outdoor weathering were taken from various sampling locations, as shown in Appendix 2. Location 1 is an area with many visible starshaped cracks on the surface of membranes. Location 2 is an area where a strong colour variation of the membranes was observed. Location 3 is a softening roofing area where a significant deterioration in the strength of the insulation has been observed. Plasticized PVC membranes were taken from each of these roofing areas, immediately wrapped in polyethylene, and transported to the laboratory for further analysis.

Plasticized PVC membranes are produced by caste spreading, whereby a spreading head applies a substrate of a liquid-viscosity raw material called "plastisol". The spreading and gelation process is repeated four times, creating a membrane of four differently formulated layers. Between the second and third layers an inner reinforcing layer of polyester mesh is inserted. This process creates a molecular bond between the layers, resulting in a homogeneous, elastic, single-layer membrane. ${ }^{15}$

\section{2. Mechanical Testing}

The mechanical performance of new, unused PVC membranes and aged membranes from the roof area was measured with a Zwick/Roell Z010 universal testing machine according to standard EN 12311-2. The length of the samples was $200 \mathrm{~mm}$ and width $50 \mathrm{~mm}$. At an elongation of $1 \%$ and $2 \%$, the secant modulus of elasticity was measured at a cross-head speed of $1.25 \mathrm{~mm} / \mathrm{min}$. After exceeding a deformation of $2 \%$, samples were measured with a test cross-head speed of $200 \mathrm{~mm} / \mathrm{min}$ until they broke. All specimens were tested in longitudinal and transverse directions using the same test method under laboratory conditions $T=393.15 \pm 2 \mathrm{~K}, \mathrm{RH}$ (relative humidity) $=50 \pm 5 \%$.

\section{3. Contact Angle Measurement}

The wettability of plasticized membranes was assessed with an exact experimental procedure. Droplets of milli-Q water (a specific resistance of $18.2 \mu \Omega$ ) with exact sizes of $10 \mu \mathrm{l}$ were formed on a membrane with a micropi- pette. Droplets were filmed with a Basler Aca1300-200um digital camera equipped with a Basler Premium Lens with C-mount, connected to a computer using the OpenDrop algorithm to calculate the contact angles. ${ }^{16}$ To avoid optical aberrations and the fake reflections from other sources that can occur at the drop edge, the drop of was lit from the opposite side with a diffusion light, which was achieved by placing a glass diffuser between the light source and the sessile drop. The undesired effect of drop oscillation was minimized by using an anti-vibration table.

\section{4. Thickness Evaluation, Surface Morphology and Chemical Characterization}

The thickness evaluation and morphological changes in aged membrane microstructure were scanned using ESEM (Environmental Scanning Electron Microscopy) Quanta 200 3D (FEI Company, Hillsboro, OR). Chemical modifications were identified and quantified using Fourier Transform Infrared Spectroscopy (FTIR) analysis on a Bruker Tensor 27 DTGS spectrometer in attenuated total reflection (ATR) mode between 4000 and $450 \mathrm{~cm}^{-1}$ with an average of 32 consecutive scans and a resolution of $4 \mathrm{~cm}^{-1}$.

\subsection{Low-temperature Flexibility}

Low-temperature flexibility is an important membrane property, especially during the application phase. Normally, the flexibility of membranes decreases significantly along with the surrounding temperature. ${ }^{9}$ A test of low-temperature resistance was carried out according to the SIST EN 495-5 standard. This European Standard specifies a method for the determination of the behaviour of plastic and rubber sheets for waterproofing to folding after exposure at a low temperature. The examined samples were folded at $180^{\circ}$ and conditioned for $12 \mathrm{~h}$ at low temperatures in a chamber. The occurrence of cracks in the samples indicates that the material is not resistant to low temperatures.

\section{6. Thermal Degradation}

Thermogravimetric analysis and thermal transition of material samples were carried out using a TGA/DSC (Differential Scanning Calorimetry) instrument (Mettler Toledo). The investigated material was placed in separate vials and heated in an $\mathrm{N}_{2}$ atmosphere at a rate of $20 \mathrm{~K} /$ min from $298 \mathrm{~K}$ to $1273 \mathrm{~K}$. Mass loss was measured as a consequence of thermal degradation of membrane layers.

\section{Results and Discussion}

\section{1. Mechanical Performance}

The maximum tensile strength in $\mathrm{MPa}(\boldsymbol{\sigma})$ and the elongation at break in \% $(\varepsilon)$ were determined for samples 
after 10 years of use and the values were compared with those of new samples (Figures 2 and 3). Three samples were tested from each sampling location. As can be seen in Figure 3 , there is a small variation in tensile strength in the longitudinal direction of aged membranes. It appears that the polyester mesh is well encapsulated within the membrane matrix and has not degraded over time. In addition, there is a tendency for tensile strength to increase with age, as the membrane loses flexibility over time. ${ }^{9}$ Similar observations were made in a study by Blanco et al. ${ }^{10}$, where both load and tensile strength in longitudinal and transversal

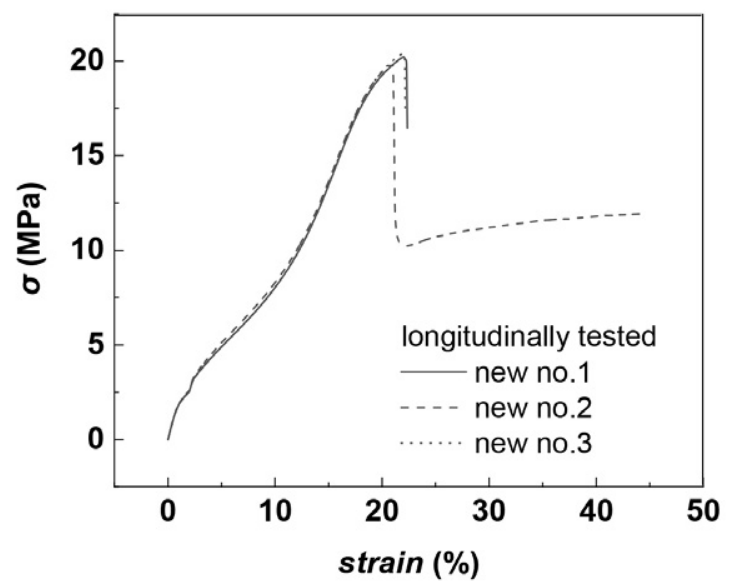

directions were evaluated for 35-year-old geomembranes with reinforced polyester.

On the other hand, the strength of aged membranes decreases in the transverse directions compared to the strength of a new membrane. As shown in Table 1, aged membrane samples showed a shorter elongation at break than that of the new membrane. This indicates a loss of flexibility caused by natural aging under high humidity and thermal fluctuations. The deterioration in elastic properties is caused by the loss of plasticizers as a result of a long period of combined exposure to heat from solar

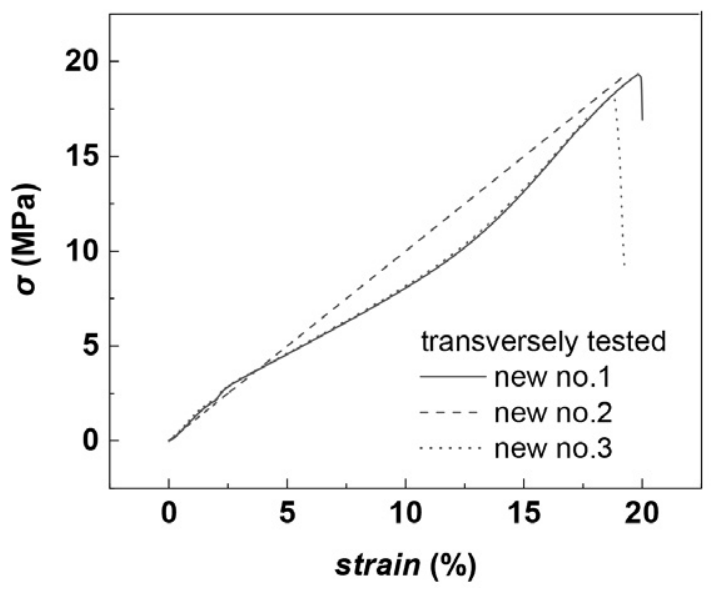

Figure 2. Tensile strength and elongation at break (load/strain curves) for new plasticized PVC membrane samples tested longitudinal (left) and transverse (right) directions at conditions: $T=393.15 \pm 2 \mathrm{~K}, \mathrm{RH}$ (relative humidity) $=50 \pm 5 \%$.
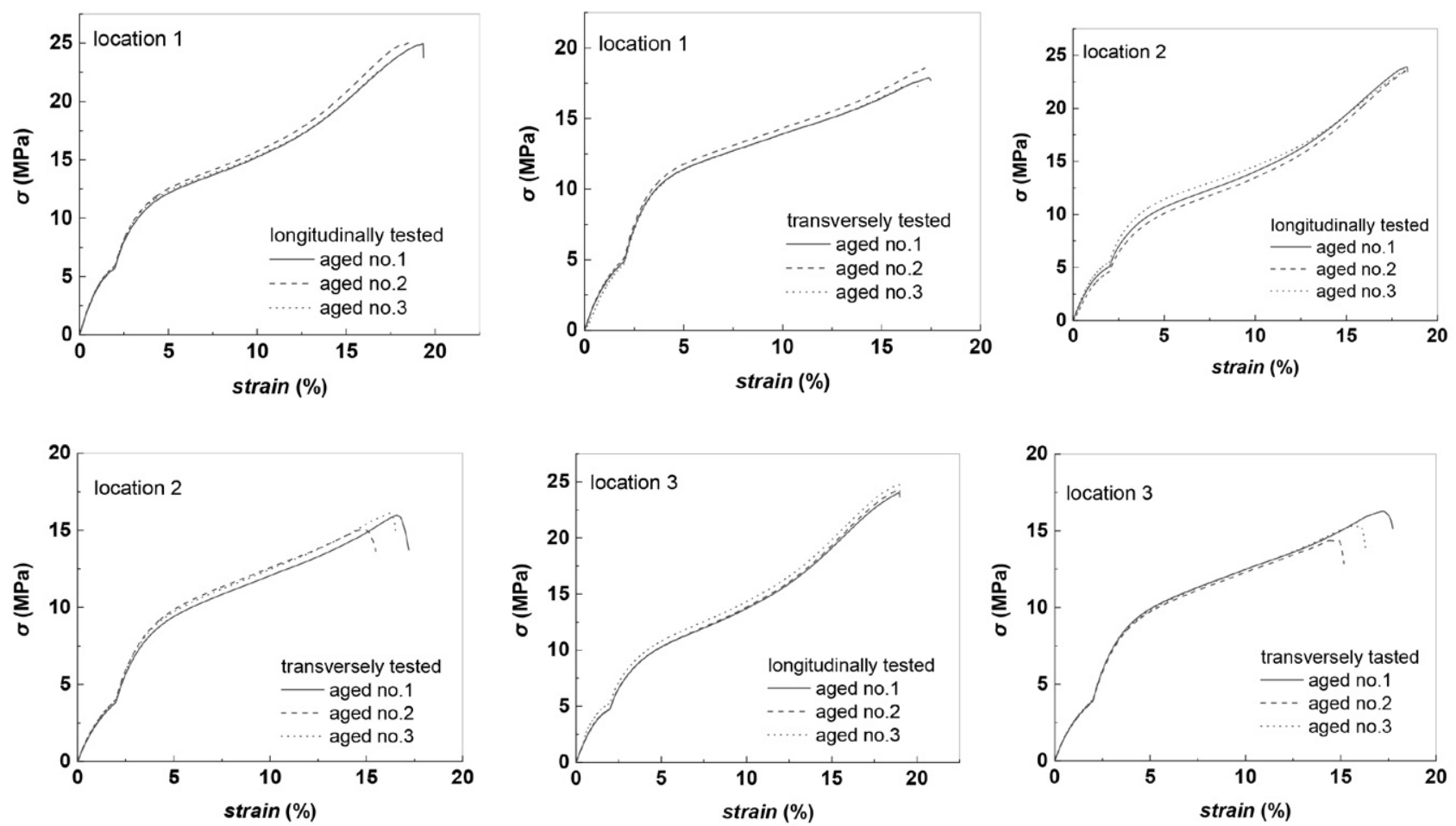

Figure 3. Tensile strength and elongation at break (load/strain curves) for aged, plasticized PVC membrane samples tested longitudinal (left) and transverse (right) directions at conditions: $T=393.15 \pm 2 \mathrm{~K}, \mathrm{RH}$ (relative humidity) $=50 \pm 5 \%$. 
radiation, ear-ultraviolet radiation, atmospheric oxidation, humidity and air pollution. ${ }^{17}$ It was found that the influence of plasticizer content has a certain influence on elongation, but a mixed influence on the tensile strength of membranes reinforced with polyester mesh. Despite sufficient tensile strength, the wettability properties of these membranes were strongly influenced by age.

Table 1. Tensile strength and elongation at break.

\begin{tabular}{lcccc}
\hline Sample & $\boldsymbol{\sigma}(\mathbf{M P a})$ & $\boldsymbol{\varepsilon}(\%)$ & $\boldsymbol{\sigma}(\mathbf{M P a})$ & $\boldsymbol{\varepsilon}(\%)$ \\
\hline \multirow{2}{*}{ longitudinally } & \multicolumn{2}{c}{ transversely } \\
\hline \multirow{2}{*}{ Lew } & 20.23 & $\mathbf{2 2 . 3 6}$ & 19.17 & $\mathbf{2 0 . 0 1}$ \\
& 18.68 & $\mathbf{4 4 . 5 4}$ & 19.27 & $\mathbf{2 0 . 5 1}$ \\
& 20.43 & $\mathbf{2 2 . 1 6}$ & 18.17 & $\mathbf{1 9 . 2 8}$ \\
\hline \multirow{2}{*}{ Location 2 } & 23.90 & $\mathbf{1 8 . 3 6}$ & 15.91 & $\mathbf{1 7 . 2 1}$ \\
& 23.55 & $\mathbf{1 7 . 3 1}$ & 15.04 & $\mathbf{1 5 . 4 9}$ \\
& 23.70 & $\mathbf{1 8 . 3 9}$ & 16.12 & $\mathbf{1 6 . 5 1}$ \\
\hline Location 3 & 24.01 & $\mathbf{1 9 . 9 6}$ & 16.26 & $\mathbf{1 8 . 9 6}$ \\
& 24.26 & $\mathbf{1 9 . 9 9}$ & 14.38 & $\mathbf{1 7 . 7 3}$ \\
& 25.27 & $\mathbf{1 9 . 9 6}$ & 15.29 & $\mathbf{1 6 . 2 9}$ \\
\hline
\end{tabular}

\section{2. Contact Angle and Wettability}

The surface wettability of the membranes was evaluated by measuring the contact angles of sessile droplets. As can be seen from Table 2, the contact angles of new plasticized PVC membranes remain almost constant within 180 seconds and have a significantly higher initial contact angle compared to the aged samples. In contrast, the contact angle for aged membranes is significantly reduced from $56.1^{\circ} \pm 2.5^{\circ}$ at $10 \mathrm{~s}$ to $16.5^{\circ} \pm 4.5^{\circ}$ at 30 seconds and becomes zero after 120 seconds (Table 3, 4 and 5). Despite the good mechanical performance, the water repellence of these membranes is strongly impaired. Increasing the hydrophilicity of the aged membrane increases the unwanted water permeability and can cause damage in other roof layers. ${ }^{18}$

\section{3. Surface Morphology}

As mentioned above, the distribution and loss of plasticizer in the membrane can play an important role in tensile strength and elongation at break as well as in wettability properties. Change in surface of membranes that may result in the loss of plasticizer was also demonstrated by observation of micrographs from scanning electron microscopes (SEM).

\section{3. 1. Microstructure}

Microphotographs of new and aged membranes taken by SEM show significant differences between them. As shown in Figure 4, new membranes have a smooth surface, without cracks. Locally, only the grains of filler can be observed. In contrast, aged membranes that have been exposed to natural weathering show irritated surfaces with many cracks, agglomerates and craters as a result of plasticizer loss. The material becomes stiffer, which leads to

Table 2. Time-dependent contact angles of water droplets on new plasticized PVC membranes.

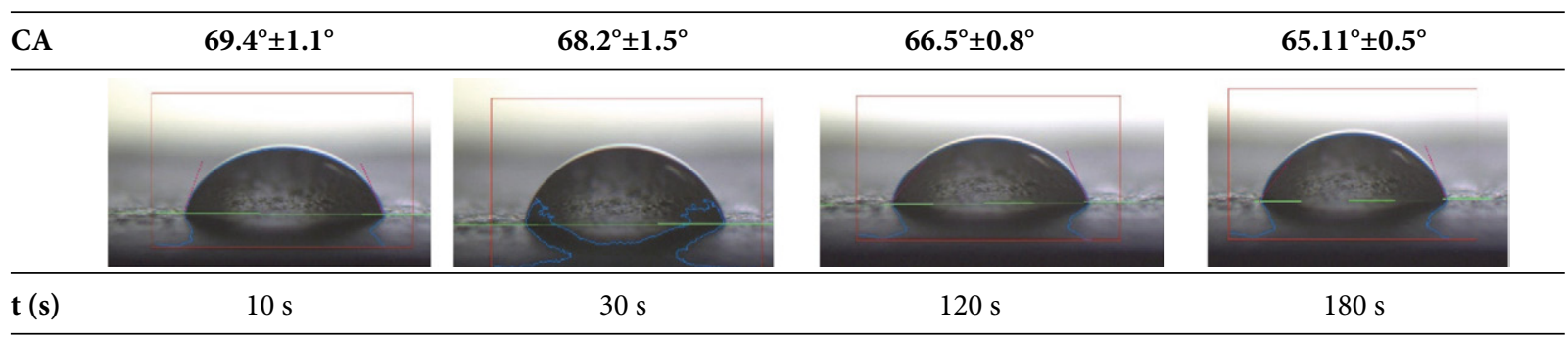

Table 3. Time-dependent contact angles of water droplets on naturally aged and damaged plasticized PVC membranes (location 1).

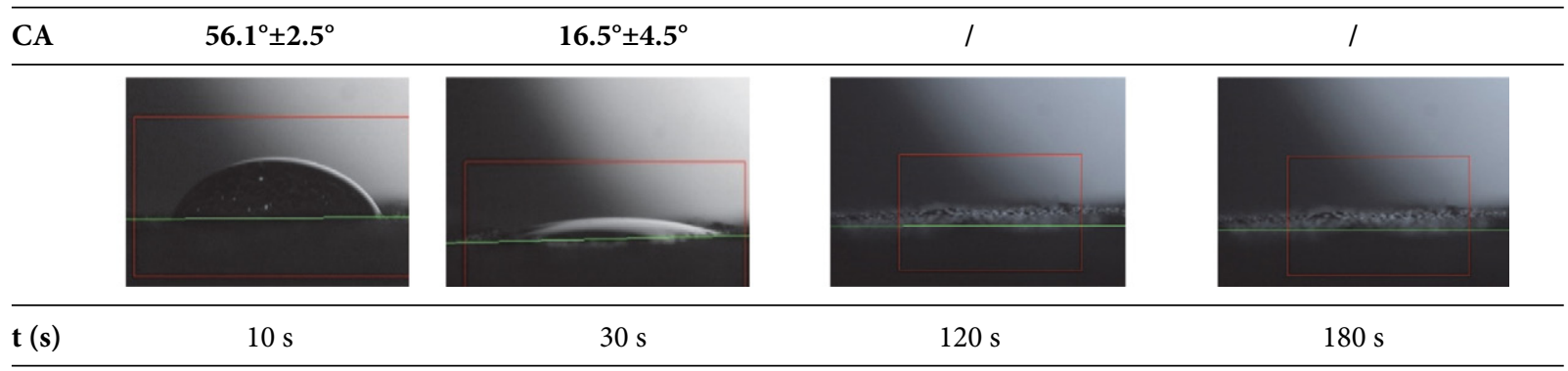


Table 4: Time-dependent contact angles of water droplets on naturally aged and damaged plasticized PVC membranes (location 2).

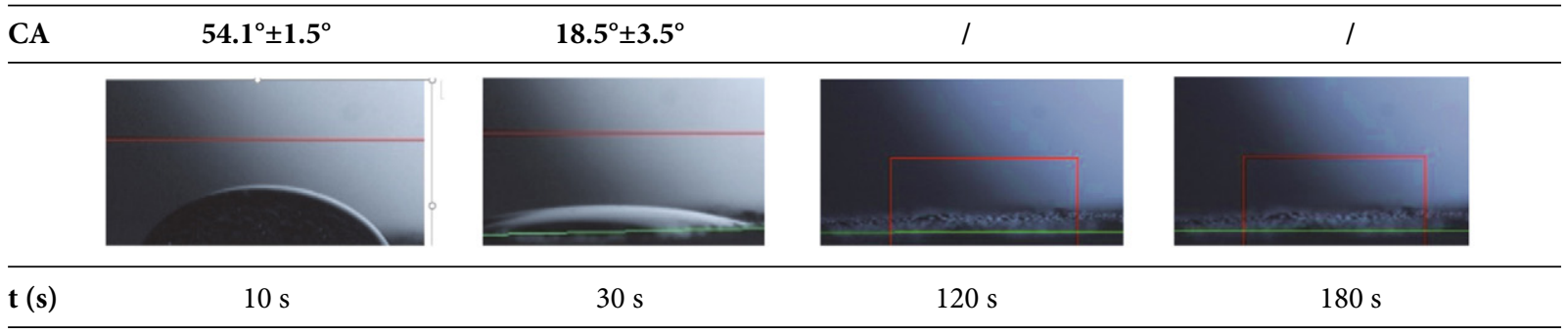

Table 5: Time-dependent contact angles of water droplets on naturally aged and damaged plasticized PVC membranes (location 3).

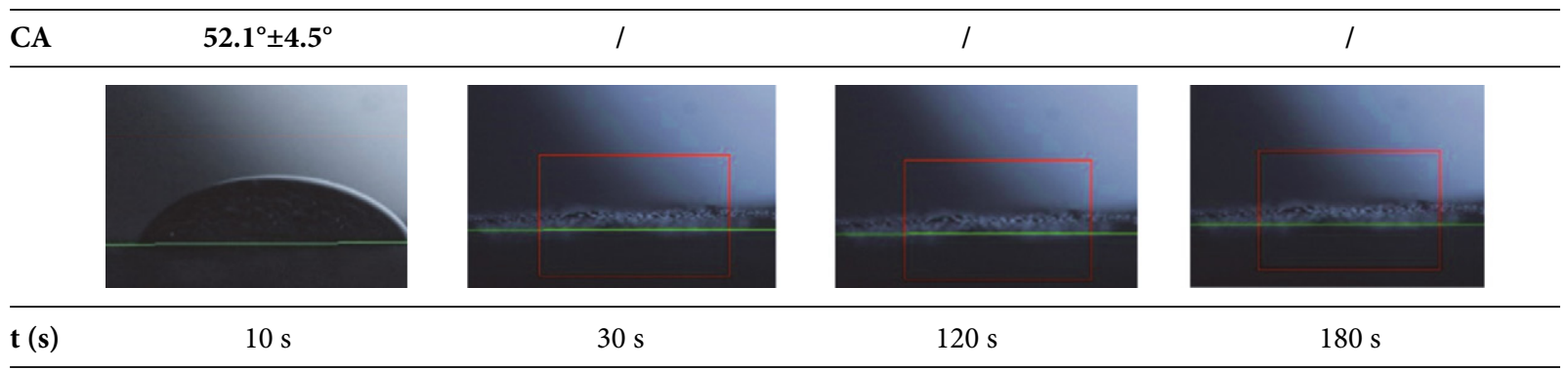
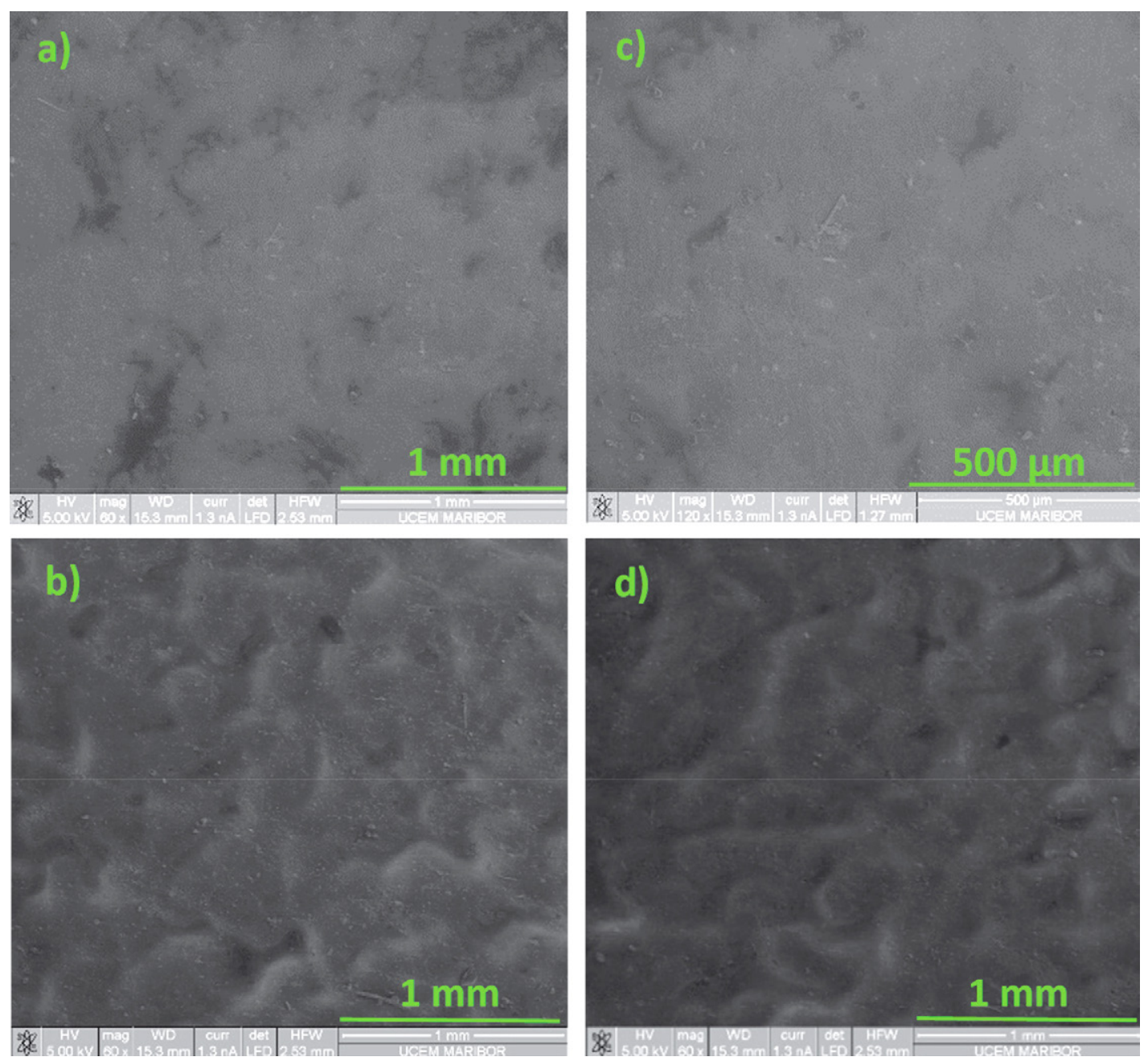

Figure 4. Microstructure of new membranes' upper layer (a, c) and lower layer (b, d). 

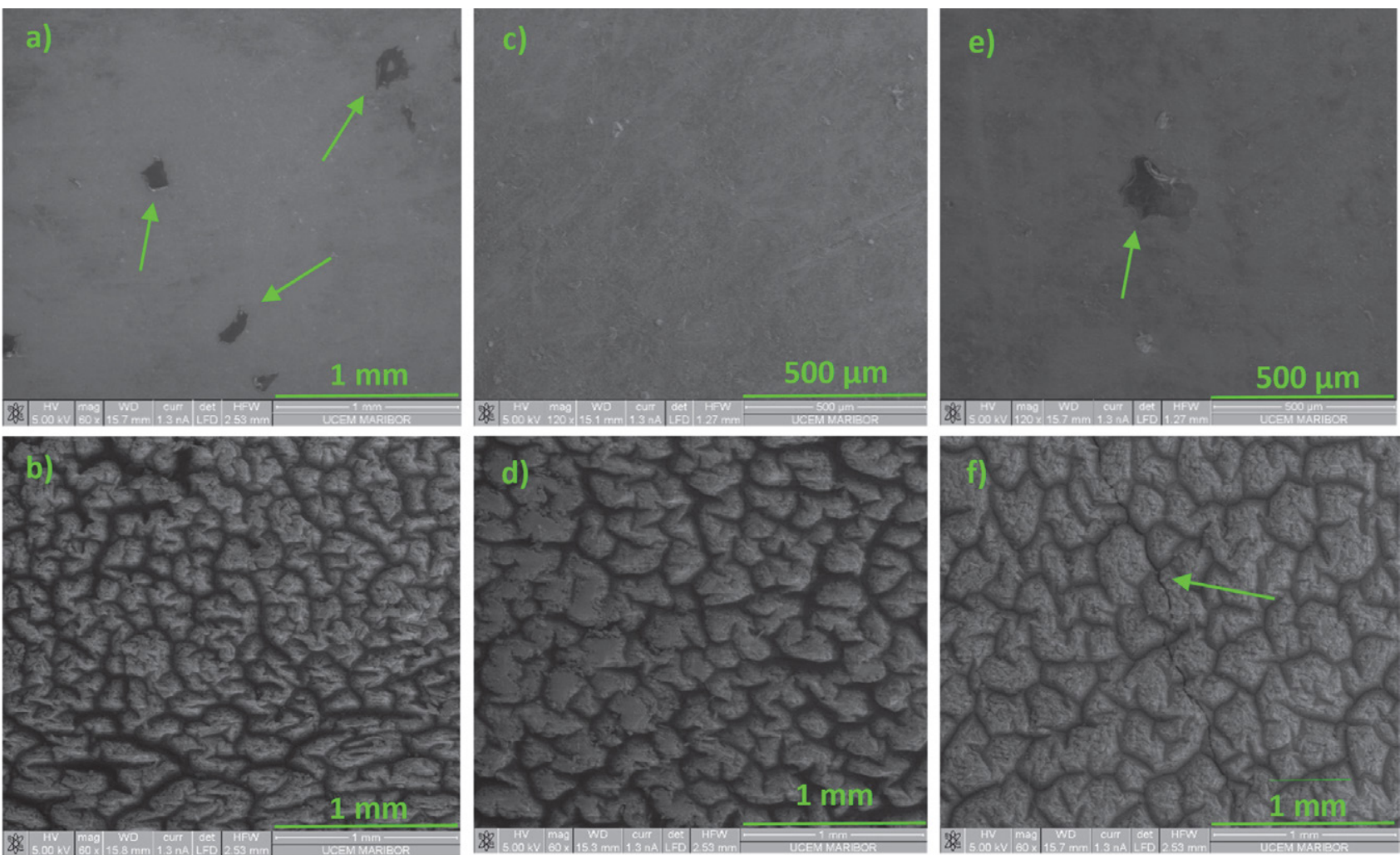

Figure 5. The microstructure of aged membranes extracted from different sampling locations: 1 (a, b), 2 (c, d), and 3 (e, f). The surface is more heterogeneous, with many craters, cracks, agglomerates, and voids.

contractions and the prevalence of voids (Figure 5). It is assumed that the rearrangement and aggregation of molecular chains are the main mechanisms of membrane degradation. ${ }^{19}$ Pedrosa et al. ${ }^{20}$ presented an interesting study using X-ray spectroscopy and SEM analysis of membranes exposed to different weathering conditions. They reported that aged membranes show numerous cracks and fractures and there is a significant decrease in chlorine content. Therefore, they suggested that dehydrochlorination may be the main mechanism of deterioration.

\section{3. 2. Thickness Evaluation}

Cross-sectional microphotographs with thickness evaluations of the investigated plasticized PVC membranes are presented in Figure 6 and Table 6. It can be seen that the thickness of the aged membranes is decreased. As can be seen in Figure 6, there is also a visible difference in cross-sectional area between new and aged membranes.

Table 6. Thickness of the new and aged membranes.

\begin{tabular}{lcc}
\hline Samples & Average value $(\mathbf{m m})$ & Standard deviation (\%) \\
\hline Location 1 & 1.17 & 1.25 \\
Location 2 & 1.11 & 1.63 \\
Location 3 & 1.09 & 1.63 \\
\hline New & 1.18 & 2.05 \\
\hline
\end{tabular}
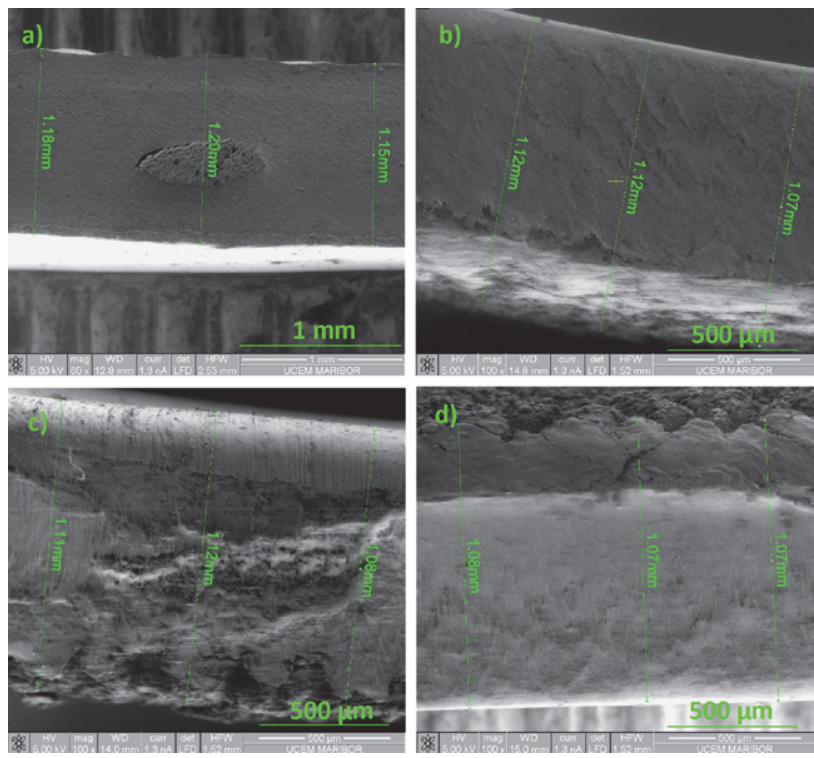

Figure 6. Microphotographs in cross section with thickness evaluation for new membrane (a) and aged membranes (a, b, c).

For example, the average thickness values for location 3 decrease from $1.18 \mathrm{~mm}$ to $1.09 \mathrm{~mm}$. Changes in material thickness might be because of the reduction of plasticizer content. To justify plasticizer loss in material, chemical changes were identified and quantified using ATR/FTIR analysis. 


\section{4. ATR/FTIR Analysis}

FTIR spectra were recorded to investigate the chemical changes in the aged membranes from location 3 (with the highest exposed to solar radiation, near-ultraviolet radiation, atmospheric oxidation and moisture. Both the front (directly exposed to weathering) and side (inverted next to the insulation material) surfaces of the membranes were examined (Table 7, Figure 7 and 8). In FTIR, the spectra appearance of several characteristic bands can be seen. In particular, the $\mathrm{C}=\mathrm{O}$ stretching vibration of the ester function from plasticizer is detected at $1720.50 \mathrm{~cm}^{-1}$. O-H bending is detected at $1425.40 \mathrm{~cm}^{-1}$ and symmetric and antisymmetric vibrations of the ester $\mathrm{C}-\mathrm{O}-\mathrm{C}$ group in the region $1072.42-1280.08 \mathrm{~cm}^{-1}$. At the front side of aged membrane new peaks appear at $1660.71-1618.28 \mathrm{~cm}^{-1}$ that are associated with the stretching of the $\mathrm{C}=\mathrm{C}$ bonds of the aromatic ring, indicating that chemical degradation appeared in the membrane molecules ${ }^{21}$. Compared to the front side of new membranes, the characteristic $\mathrm{C}-\mathrm{Cl}$ stretching vibration at $642.95-605.65 \mathrm{~cm}^{-1}$ is not visible. This suggests that UV aging could have caused a dehydrochlorination reaction. These data are consistent with changes in the

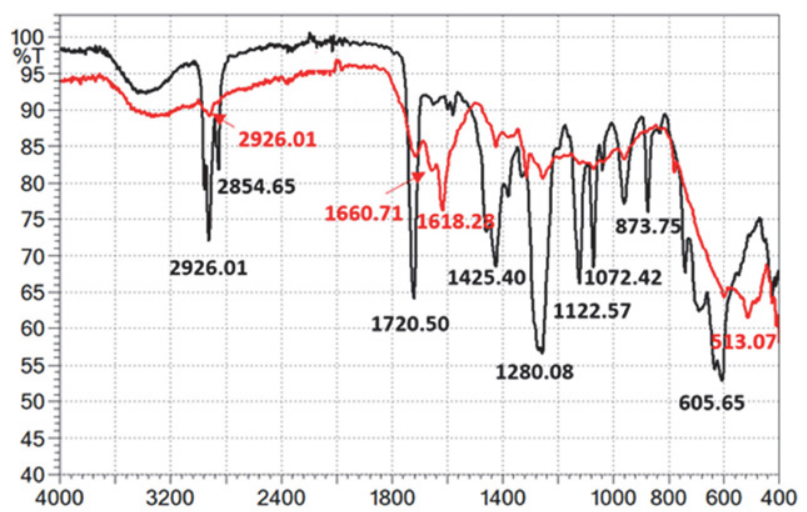

Figure 7. FTIR spectra at the front side of the new plasticized membranes (black line) and aged membranes (red line) operating in attenuated total reflection (ATR) mode.

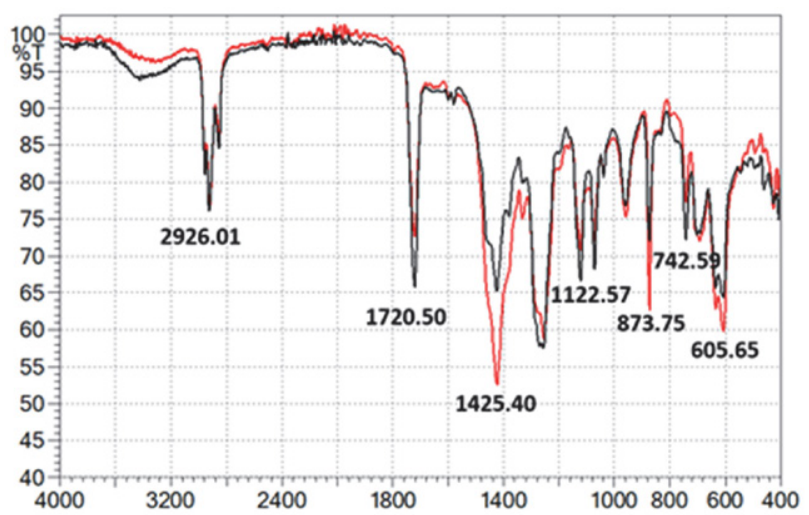

Figure 8. FTIR spectra at the back side of the plasticized membranes (black line) and aged membranes (red line) operating in attenuated total reflection (ATR) mode. membrane morphology and elongation properties. On the back side of the membranes there is no visible difference in spectra between new and aged samples. The $\mathrm{C}-\mathrm{H}$ stretching mode can be observed at $2954.95-2852.72 \mathrm{~cm}^{-1}$ and the trans $\mathrm{C}-\mathrm{H}$ wagging mode at $873.75 \mathrm{~cm}^{-1} 22$.

Table 7: Main FTIR bands for the front and back sides of plasticized PVC membranes.

\begin{tabular}{lll}
\hline & Wavenumber, $\mathbf{~ c m}^{-\mathbf{1}}$ & Chemical Group \\
\hline Front side (new) & $2954.95-2854.65$ & C-H stretching \\
vibration & 1720.50 & C=O stretching \\
& $1425.40-1379.10$ & O-H bending \\
& 1280.08 & C-O stretching \\
& $1122.57-1039.63$ & C-O stretching \\
& 873.75 & C-H bending \\
& $740.67-605.65$ & C-Cl stretching \\
\hline Front side (aged) & 2926.01 & C-H stretching \\
& $1660.71-1618.28$ & C=C stretching \\
& 1253.73 & C-O stretching \\
\hline Back side & $2954.95-2852.72$ & C-H stretching \\
(new and aged) & 1720.50 & C=O stretching \\
& & vibration \\
& 1425.40 & O-H bending \\
& 1122.57 & C-O stretching \\
& $742.95-605.65$ & C-Cl stretching \\
\hline
\end{tabular}

\subsection{Low-temperature Flexibility}

Three $50 \mathrm{~mm}$ wide rectangular samples from each sampling location were folded between two metal plates and then stored in a chamber to allow them to cool to the desired test temperature. In the first experiment, all samples were subjected for $12 \mathrm{~h}$ to the temperature of $248 \mathrm{~K}$ $\left(-25^{\circ} \mathrm{C}\right)$. New samples meet the requirement according to the standard SIST EN 495-5 and stay unaltered after $180^{\circ}$ bending around a small radius. In contrast, the flexibility of all aged membranes decreased significantly. Visible cracks were observed on the surface of the membranes and it was also possible to see into the polyester reinforcement in the upper layer of the membrane.

In the second experiment, the lowest temperature at which aged samples stay visually unaltered (without cracking) was recorded (Figure 9 a). The reproducibility of the test method was $\pm 5 \mathrm{~K}$. There is a clear difference in low temperature flexibility between new and aged membranes. As can be seen in Figure 9, aged membranes are resistant to low temperature bending up to $278 \pm 5 \mathrm{~K}$, while new ones are resistant to $238 \mathrm{~K}$. The results are in accordance with those in a study by Beer et al., who performed similar tests on PVC membranes after long-term exposure. ${ }^{9}$ Although flexibility is mainly an issue during installation and roof maintenance, the obtained results are important to understand the long-term behaviour of membranes. 

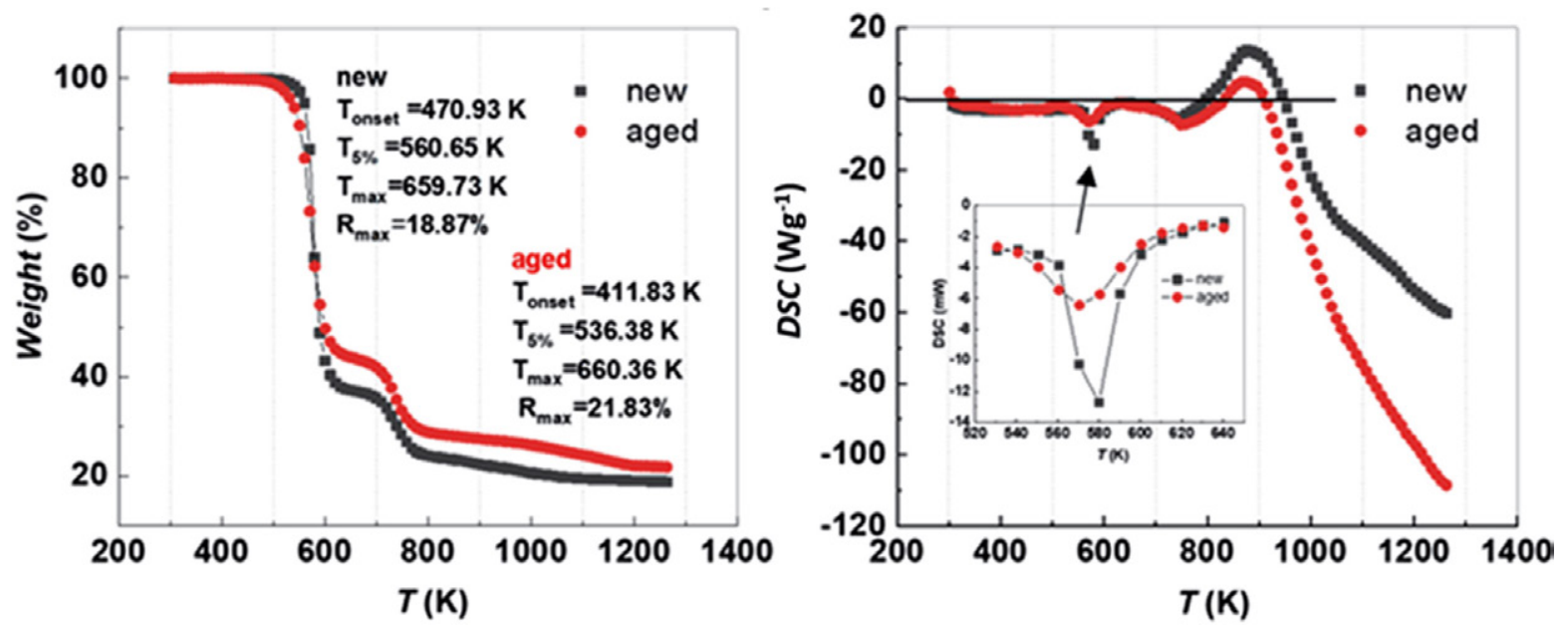

Figure 9. The lowest temperature at which aged samples stay visually unaltered (a). Cracks were observed along the upper layer of aged membranes after exposure to the temperature of $248 \mathrm{~K}\left(-25^{\circ} \mathrm{C}\right)(\mathrm{b})$.

\section{6. TGA-DSC Analysis}

Figure 10 shows the thermal properties of a new membrane and an aged membrane (from location 3 ) heated in nitrogen at a temperature range from $298 \mathrm{~K}$ up to $1273 \mathrm{~K}$. The TG characteristic temperatures of the membranes are illustrated in Figure 10, including the onset temperature $\left(T_{\text {onset }}\right), 5 \%$ weight loss temperature $\left(T_{5 \%}\right)$, the temperature at the maximum degradation rate $\left(T_{\max }\right)$, and the maximum degradation rate $\left(R_{\max }\right)$. It can be observed that new membranes have relatively high thermal stability below $470.93 \mathrm{~K}$. In the case of aged membranes, the weathering effects led to a decrease in the $T_{\text {onset }}$ value from $470.93 \mathrm{~K}$ to $411.83 \mathrm{~K}$, and for $T_{5 \%}$ from $560.65 \mathrm{~K}$ to $536.38 \mathrm{~K}$. This seems to confirm that weathering aging over a long period of time resulted in degradation of the membrane molecules, as suggested by FTIR analysis.

The initial negative heat flux shows that the decomposition reactions occur due to the heating of PVC, plasticizers and polyester mesh. In this step, dehydrochlorination takes place, producing $\mathrm{HCl}$ molecules. ${ }^{23}$ In the temperature range from $540 \mathrm{~K}$ to $650 \mathrm{~K}$, both membranes show a characteristic endothermic deviation from baseline, which is more evident in a new sample (Figure 10). The increase in heat flux at about $880 \mathrm{~K}$ could correspond to an exothermic transformation caused by crystallization of the samples. $\mathrm{HCl}$ is released from the melt and the molecules are rearranged by cross-linking reactions. Above $1273 \mathrm{~K}$, the total charring of the membranes corresponds to a high negative heat flux.

\section{Conclusions}

The results of the measurements reaffirmed the sensitivity of plasticized PVC membranes reinforced with polyester mesh used for mechanically fixed unvented roof
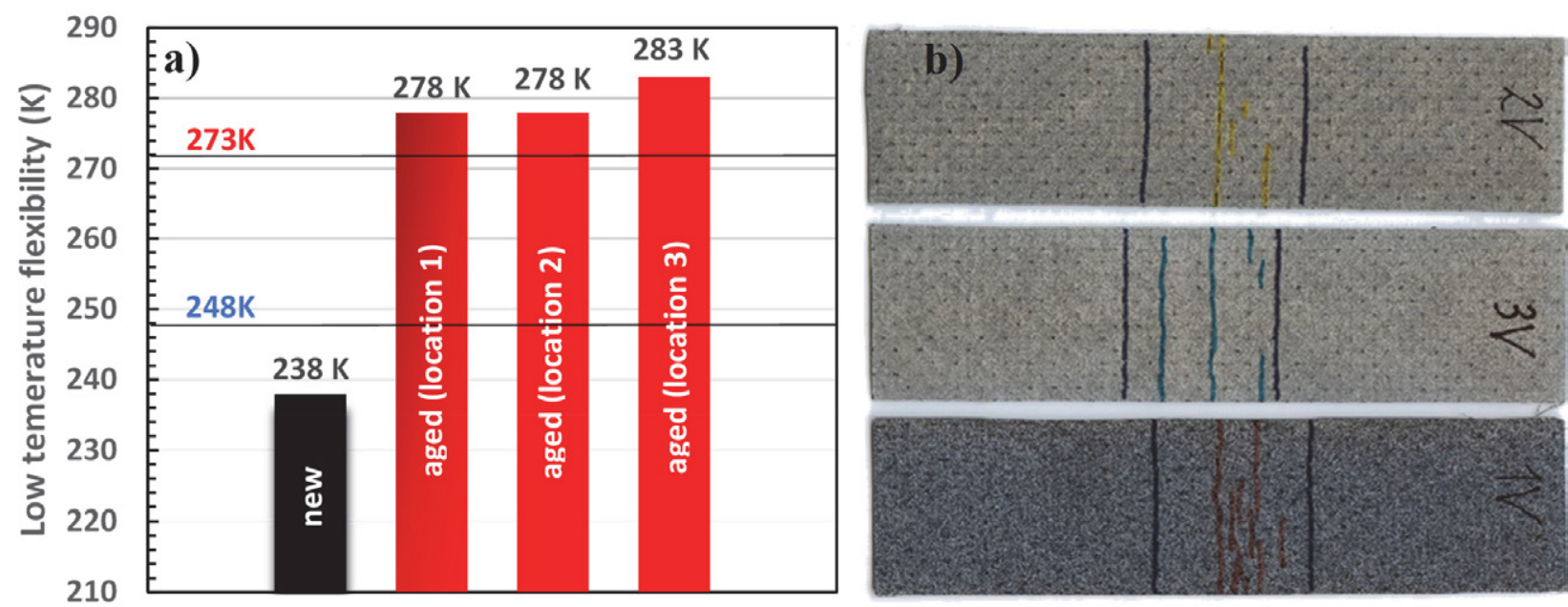

Figure 10. Results of the TGA-DSC analysis for new and aged membranes from location 3. 
systems over thermal insulation. During 10 years of use, plasticized PVC gradually degraded, and its primary physical, chemical and mechanical properties changed. This tendency was observed in all three sampling locations. Therefore, the roofing area had to be completely replaced. The main conclusions are:

- there is a tendency for tensile strength to increase with age. It appears that the polyester mesh is well encapsulated within the membrane matrix,

- aged membrane samples exhibited shorter elongation at break than new ones. This indicates a loss of flexibility under high humidity and thermal fluctuations,

- wettability properties of examined membranes were highly affected by age,

- the surface of aged membranes is more heterogeneous that that of new ones, containing many craters, cracks, agglomerates, and voids. Similarly, the thickness of the aged membranes decreased probably due the migration of plasticizer content,

- FTIR analysis confirmed the chemical changes in aged membranes. New peaks appear at 1660.71$1618.28 \mathrm{~cm}^{-1}$, indicating that chemical degradation had occurred in the membrane molecules,

- when low-temperature flexibility tests were performed, visible cracks were observed along the aged membranes,

- thermal analysis revealed that the weathering aging effects resulted in reductions of $T_{\text {onset }}$ and $T_{5 \%}$.

To reduce degradation and increase the durability of PVC membranes, new durable additives and plasticizers that are resistant to heat from solar radiation, near-ultraviolet radiation, atmospheric oxidation and moisture should be used. In future studies, we will use time-temperature superposition models to assess the effect of aging on waterproofing membranes.

\section{Acknowledgments}

The authors would like to acknowledge the Slovenian Research Agency (ARRS) for partly financing this research within the frame of program P2-0046.

\section{Conflicts of Interest}

The authors declare no conflict of interest.

\section{References}

1. Y. Ma, S. Liao, Q. Li, Q. Guan, P. Jia and Y. Zhou, React Funct Polym. 2020, 147, 637-642.

2. Z. Kormosh, I. Hunka and Y. Bazel, Acta Chim. Slov. 2008, 55, 261-267. DOI:10.1002/jccs.200800052

3. M. Shamsipur, S. Sahari, M. Payehghadr and K. Alizadeh, Acta Chim. Slov. 2011, 58, 555- 562.
4. M. Zagorodnikova, V. Yartsev and V. Rupyshev, Adv. Mater. Technol. 2019, 2, 41-47.

5. M. Londschien and M. Bonnet, J. Appl. Polym. Sci. 2018, 135, 46689. DOI:10.1002/app.46689

6. P. Dunn, D. Oldfield and R. Stacewicz, J. Appl. Polym. Sci. 1970, 14, 2107-2116. DOI:10.1002/app.1970.070140818

7. L. Audouin, B. Dalle, G. Metzger and J. Verdu, J. Appl. Polym. Sci. 1992, 45, 2091-2096. DOI:10.1002/app.1992.070451204

8. M. Ito and K. Nagai, Polym. Degrad. Stab. 2007, 92, 260-270. DOI:10.1016/j.polymdegradstab.2006.11.003

9. H. Beer, A. Delgado, R. Paroli and S. Graveline: 10DBMC International Conference On 10. Durability of Building Materials and Components LYON, International AG, Industriestrasse, Lyon, France 2005, 1-7.

10. M. Blanco, N. Touze-Foltz, M. Pérez Sánchez, M. Redón-Santafé, F.-J. Sánchez Romero, J. B. Torregrosa Soler and F. A. Zapata Raboso, Geosynth. Int. 2018, 25, 85-97. DOI:10.1680/jgein.17.00035

11. A. Kositchaiyong, V. Rosarpitak, H. Hamada and N. Sombatsompop, Int. Biodeterior. Biodegradation 2014, 91, 128-137. DOI:10.1016/j.ibiod.2014.01.022

12. M. Gonçalves, J. D. Silvestre, J. de Brito and R. Gomes, J. Build. Eng. 2019, 24, 100710. DOI:10.1016/j.jobe.2019.02.002

13 R. Paolini, M. Zinzi, T. Poli, E. Carnielo and A. G. Mainini, Energy Build. 2014, 84, 1 333-343.

DOI:10.1016/j.enbuild.2014.08.008

14. A. Ivanič, G. Kravanja, W. Kidess, R. Rudolf and S. Lubej, Materials, 2020, 13, 2392. DOI:10.3390/ma13102392

15. Flagon, https://pdf.archiexpo.com/pdf/soprema/flagon/3193 $-66009 . h t m l$.

16. E. Huang, A. Skoufis, T. Denning, J. Qi, R. R. Dagastine, R. F. Tabor and J. D. Berry. J. Open Source Softw. 2021, 58, 2604

17. M. Lenartowicz, B. Swinarew, A. Swinarew and G. Rymarz, Int. J. Polym. Anal. Charact. 2014, 19, 611-624.

DOI:10.1080/1023666X.2014.933071

18. A. Behboudi, Y. Jafarzadeh and R. Yegani, Chem. Eng. Res. Des. 2016, 114, 96-107. DOI:10.1016/j.cherd.2016.07.027

19. Y. Fu and J. R. Lakowicz, Nature, 2011, 472, 178-179. DOI:10.1038/472178a

20. A. Pedrosa and M. Del Río, Materiales de Construcción 2017, 67, 109. DOI: $10.3989 / \mathrm{mc} .2017 .08915$

21. A. Royaux, I. Fabre-Francke, N. Balcar, G. Barabant, C. Bollard, B. Lavédrine and S. Cantin, Polym. Degrad. Stab. 2017, 137, 109-121. DOI:10.1016/j.polymdegradstab.2017.01.011

22. S. Ramesh, K. H. Leen, K. Kumutha and A. K. Arof, Spectrochim. Acta A Mol. Biomol. Spectrosc. 2007, 66, 1237-1242.

23. A. Marongiu, T. Faravelli, G. Bozzano, M. Dente and E. Ranzi, J Anal Appl Pyrolysis. 2003, 70, 519-553.

DOI:10.1016/S0165-2370(03)00024-X 


\section{Povzetek}

$\mathrm{Z}$ namenom ugotoviti vzroke degradacije in preučitve vplivov naravnega staranja na obstojnost plastificiranih polivinilkloridih membran, smo izvedli vzorčenje poškodovanih membran iz industrijskih strešnih kritin in jih primerjali $\mathrm{z}$ novimi. Določili smo natezne trdnosti, stopnjo elongacije do pretrga, in omočljivost membran. Nato smo z uporabo skenirane elektronske mikroskopije (SEM) analizirali morfološke mikrostrukturne spremembe in določili debeline membran. Za preučevanje kemijskih sprememb v starih membranah smo uporabili Fourierevo analizo z infrardečo spektroskopijo (FTIR). Z namenom preučevanja toplotne razgradnje smo uporabili termogravimetrično analizo in diferenčno dinamično kalorimetrijo (TGA-DSC). Rezultati nakazujejo na očitne spremembe mehanskih, fizikalnih in kemijskih lastnosti poškodovanih membran, kar nakazuje na zmanjšanje vsebnosti plastifikatorja. Površina membran postane trša, kar povzroči krčenje in razširjenost praznin. Povprečne debeline membran na preseku se zmanjšajo. Zaradi degradacije hidroizolacije iz plastificiranega PVC-ja, je bilo strešno kritino potrebno zamenjati v celoti. 